\title{
Differential Scanning Calorimetry of Bacteria
}

\author{
By CHRISTOPHER A. MILES, ${ }^{*}$ BERNARD M. MACKEY AND \\ SUSAN E. PARSONS \\ Agricultural and Food Research Council, Food Research Institute - Bristol, Langford, \\ Bristol BS18 7DY, UK
}

(Received 13 June 1985 ; revised 17 October 1985)

\begin{abstract}
Thermograms obtained by differential scanning calorimetry of a range of bacteria of different heat resistances were compared. Equations were derived to calculate the rate at which the numbers of viable organisms in a calorimeter decline as the temperature is raised at a constant rate. Vegetative bacteria scanned at $10^{\circ} \mathrm{C} \mathrm{min}{ }^{-1}$ showed multi-peaked thermograms with four major peaks (denoted $m, n, p$ and $q$ ) occurring in the regions $68-73,77-84,89-99$ and $105-110^{\circ} \mathrm{C}$ respectively. Exceptions were that peak $m$ (the largest peak) occurred at $79-82^{\circ} \mathrm{C}$ in Bacillus stearothermophilus and an additional peak, $r$, was detected in Escherichia coli at $119^{\circ} \mathrm{C}$. At temperatures below the main peak $m$ there were major differences in thermograms between species. There was a direct relationship between the onset of thermal denaturation and the thermoresistance of different organisms. Heat-sensitive organisms displayed thermogram features which were absent in the more heat-resistant types. When samples were cooled to $5^{\circ} \mathrm{C}$ and re-heated, a small endothermic peak, $p_{r}$, was observed at the same temperature as $p$. Peaks $p$ and $p_{r}$ were identified as the melting endotherms of DNA. In all vegetative organisms examined, maximum death rates, computed from published $D$ and $z$ values, occurred at temperatures above the onset of thermal denaturation, i.e. cell death and irreversible denaturation of cell components occurred within the same temperature range.
\end{abstract}

\section{INTRODUCTION}

Thermal injury to micro-organisms is known to involve particular cell components, including membranes, ribosomes and nucleic acids, yet the sequence of damaging events accompanying heating and the precise way in which these cause death of the cell remain largely unknown despite over 100 years of scientific research and commercial concern (Tomlins \& Ordal, 1976; Beuchat, 1978; Pierson et al., 1978; Pellon \& Sinskey, 1984). There are few previous calorimetric studies of the thermal denaturation of bacteria even though differential scanning calorimetry (DSC) has been used to study heat activation and spontaneous germination of bacterial spores (Maeda et al., 1974, 1975; Van Cauwelaert \& Verbeke, 1979; Verbeke et al., 1981), phase transitions in the lipids of bacterial membranes (McElhaney, 1982) and the thermal behaviour of bacterial cell water (Gonda \& Koga, 1973). Verrips \& Kwast (1977) reported that the DSC thermogram of vegetative cells of the bacterium Citrobacter freundii was composed of eight unidentified endothermic peaks. The first two, at $50^{\circ} \mathrm{C}$ and $55^{\circ} \mathrm{C}$, corresponded with the range of temperatures over which thermal death was thought to occur, but the relationship between temperature and the rate at which the number of viable organisms declined in the calorimeter was not established.

This study compares the DSC thermograms of a range of bacteria, and develops equations which allow calculation of the rate at which the number of viable micro-organisms in a calorimeter declines as their temperature is raised at a constant rate. This allows comparison of

Abbreviation: DSC, differential scanning calorimetry/calorimeter. 
the death rate with features of the DSC thermogram. A comparison is also made between the thermal denaturation of purified DNA from Escherichia coli and a reversible peak observed in whole bacteria.

\section{METHODS}

Organisms and growth conditions. Nine species of bacteria were selected as having a range of heat resistances and included Gram-negatives, Gram-positives and spore formers. The organisms were Vibrio marinus MP-1 (NCMB 1144); Pseudomonas fragi NCIB 8542 and Hafnia alvei GB59 from Dr B. G. Shaw, Food Research Institute, Bristol; Brochothrix thermosphacta C420 from Unilever Research, Bedford; Escherichia coli $\mathrm{K} 12$ strain KL16 from Dr B. Weiss, Johns Hopkins University, Md, USA; Streptococcus faecalis var. liquefaciens EBF 30/39 and Streptococcus faecium HGH5II from Dr E. M. Barnes, Food Research Institute, Norwich; Bacillus stearothermophilus NCA 1518/AS from Dr H. Dallyn, Metal Box Co., London. Washed spores of Bacillus cereus were from laboratory stocks.

Organisms were grown on tryptone soya broth (Oxoid CM129) supplemented with $0.3 \%(\mathrm{w} / \mathrm{v})$ yeast extract and solidified with $1.2 \%(\mathrm{w} / \mathrm{v})$ agar, $\mathrm{pH} 7 \cdot 3$, except for $V$. marinus which was grown on artificial seawater agar, $\mathrm{pH} 6 \cdot 1$, containing $\left(\mathrm{g} \mathrm{l}^{-1}\right) \mathrm{NaCl}, 24 ; \mathrm{KCl}, 7 ; \mathrm{MgCl}_{2} .6 \mathrm{H}_{2} \mathrm{O}, 5 \cdot 3 ; \mathrm{MgSO}_{4} .7 \mathrm{H}_{2} \mathrm{O}, 7$; yeast extract, 1 ; proteose peptone no. 3 (Difco), 5; agar, 12. Incubation times and temperatures were as follows: V. marinus, $72 \mathrm{~h}$ at $20^{\circ} \mathrm{C} ; P$. fragi, $H$. alvei and $B r$. thermosphacta, $24 \mathrm{~h}$ at $25^{\circ} \mathrm{C} ; \mathrm{E}$. coli, S. faecium, S. faecalis var. liquefaciens, $18 \mathrm{~h}$ at $37^{\circ} \mathrm{C}$; $B$. stearothermophilus, $18 \mathrm{~h}$ at $55-58^{\circ} \mathrm{C}$. Samples of bacteria for DSC were obtained by gently scraping growth from the agar surface with a spatula. Spore samples of $B$. cereus were taken from a centrifuged pellet of the aqueous spore suspension.

Calorimetry. Samples $(10-15 \mathrm{mg})$ were weighed to $\pm 0.01 \mathrm{mg}$, sealed in volatile aluminium pans and heated in a Perkin-Elmer DSC-2C at a rate of $10^{\circ} \mathrm{C} \mathrm{min}-1$ from about 10 to $120^{\circ} \mathrm{C}$. Samples were weighed before and after calorimetric measurements to check for loss of mass during heating and the results of samples showing signs of leakage were discarded. An empty pan was used as a reference and, after heating, the sample was rapidly cooled to its initial temperature. Selected samples were then re-run in the DSC to investigate the reversibility of the thermograms. The sample dry mass was determined by piercing the pan and drying it overnight in an oven at $105 \pm 1^{\circ} \mathrm{C}$. Data were collected and the calorimeter was controlled with a Perkin-Elmer data station but thermogram scans were transferred to a VAX-11/750 computer for high-resolution plotting and peak area determined by trapezoidal integration. The differences between the data collected during the first run and those collected on re-running the DSC were proportional to that component of the specific heat capacity caused by irreversible processes taking place during the first heating. The difference thermogram was useful for precise determination of the onset temperature of irreversible denaturation, $T_{0}$. Temperature and power scales were calibrated according to the manufacturer's instructions using the melting of indium and ice as standards. Some slight contamination of the samples with agar was inevitable and, as a control, thermograms of clean agar were also obtained. These showed a rather featureless thermogram, indicating that slight contamination by agar would have a negligible effect on the results.

$D N A$. Solutions of $E$. coli DNA (D2001, Sigma) were made up to $10 \mathrm{mg} \mathrm{ml}^{-1}$ in $0.001 \mathrm{M}$-sodium citrate buffer ( $\mathrm{pH} 7.0$ ) containing $0.01,0.02,0.05,0.1,0.5$ or $1.0 \mathrm{M}-\mathrm{NaCl}$ and stored on ice until required. Samples (approximately $12-15 \mathrm{mg}$ ) were transferred with a Pasteur pipette to volatile sample pans, sealed and run in the DSC at $10^{\circ} \mathrm{C} \mathrm{m^{-1 }}$ from 5 to $110^{\circ} \mathrm{C}$, cooled and re-run. The $\mathrm{G}+\mathrm{C}$ content (mol \%) of bacteria, obtained from the literature, was as follows: V. marinus, $42 \cdot 2$ (Baumann et al., 1984); Br. thermosphacta, 36.1 (Collins-Thompson et al., 1972); H. alvei, 48.4 (Sakazaki, 1984); P. fragi, $61 \cdot 2$ (De Ley, 1970); E. coli, 50 (Marmur \& Doty, 1962; Lawton et al., 1968); S. faecalis var. liquefaciens, 37.9 and S. faecium, 37.8 (Farrow et al., 1983); and B. stearothermophilus, 51 (Gibson \& Gordon, 1974).

\section{RESULTS}

\section{Comparisons of thermograms of different vegetative cells and their relationship to thermoresistance}

All the vegetative cells showed multi-peaked endothermic thermograms and these shared some common features (Fig. 1; Table 1). With the exception of B. stearothermophilus, the largest endothermic peak occurred at 68 to $73^{\circ} \mathrm{C}\left(79^{\circ} \mathrm{C}\right.$ in B. stearothermophilus). Apart from this thermophile, all vegetative cells shared similar thermograms at temperatures in the region, and in excess, of the main peak $m$ (Fig. 1). For example, the peaks designated $m, n, p$ and $q$ on the thermogram of $V$. marinus (Fig. 1) could also be identified in the other organisms. In $P$. frag $i$ peaks $p$ and $q$ were not separately resolved, whilst in $H$. alvei $n$ was small or non-existent. In some 


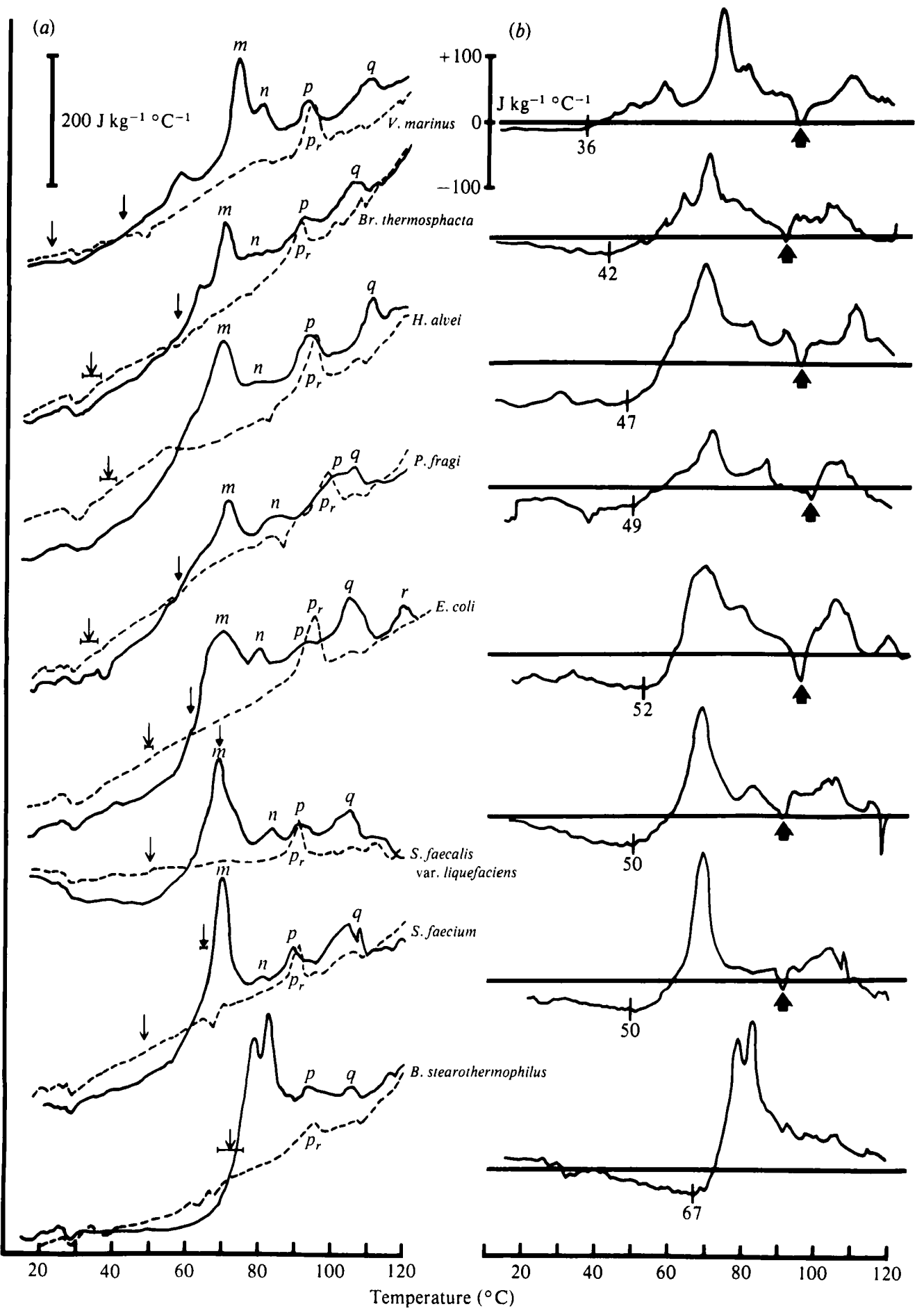

Fig. 1. Thermograms of vegetative bacterial cells. (a) Samples $\left(10-15 \mathrm{mg}\right.$ wet wt) were heated at $10^{\circ} \mathrm{C}$ $\mathrm{min}^{-1}$ from about $10^{\circ} \mathrm{C}$ to $120^{\circ} \mathrm{C}$ (solid line). After heating, each was rapidly cooled to its initial temperature and then re-heated as before (broken line). Left-hand arrow $(\downarrow)$ indicates maximum growth temperatures, right-hand arrow $(\downarrow)$ indicates temperature at which death rate is maximal (calculated as described in the Appendix, equation 14). (b) Difference plot of initial heating run minus re-run (see Methods), with values for $T_{0}$ indicated by a vertical line. Minima ( $\uparrow$ ) indicate that $p_{r}$ was larger than $p$. 
Table 1. Numerical description of bacterial thermograms [temperature $\left({ }^{\circ} \mathrm{C}\right)$ at which thermogram feature occurred]

\begin{tabular}{|c|c|c|c|c|c|c|c|c|c|c|}
\hline \multirow[b]{2}{*}{ Organism } & \multirow[b]{2}{*}{$\begin{array}{l}T_{0} * \\
\left({ }^{\circ} \mathrm{C}\right)\end{array}$} & \multirow[b]{2}{*}{$\begin{array}{l}\text { Shoulder } \\
\left({ }^{\circ} \mathrm{C}\right)\end{array}$} & \multicolumn{6}{|c|}{$\begin{array}{l}\text { Temperature of maxima } \\
\qquad\left({ }^{\circ} \mathrm{C}\right) \dagger\end{array}$} & \multirow[b]{2}{*}{ 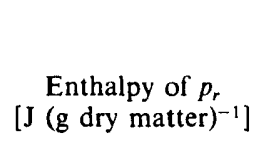 } & \multirow[b]{2}{*}{$\begin{array}{l}\text { Percentage } \\
\text { dry matter }\end{array}$} \\
\hline & & & $m$ & $n$ & $p$ & $q$ & $r$ & $p_{r}$ & & \\
\hline V. marinus & 36 & 57 & 73 & 79 & 93 & 110 & - & 94 & 1.91 & $23 \cdot 88$ \\
\hline Br. thermosphacta & 42 & 62 & 69 & 77 & 92 & 105 & - & 92 & 1.21 & $20 \cdot 54$ \\
\hline H. alvei & 47 & 61 & 69 & 79 & 93 & 110 & - & 95 & 1.81 & $23 \cdot 58$ \\
\hline P. fragi & 49 & 61 & 71 & 84 & 99 & 106 & - & 99 & $2 \cdot 31$ & 14.75 \\
\hline E. coli & 52 & - & 69 & 79 & 92 & 105 & 119 & 95 & 1.59 & $22 \cdot 19$ \\
\hline $\begin{array}{l}\text { S. faecalis var. } \\
\text { liquefaciens }\end{array}$ & 50 & - & 68 & 83 & 91 & 105 & - & 92 & $1 \cdot 12$ & 23.04 \\
\hline S. faecium & 50 & - & 69 & 81 & 89 & 105 & - & 91 & $1 \cdot 18$ & $22 \cdot 50$ \\
\hline B. stearothermophilus & 67 & - & (79) & $(82)$ & 94 & 106 & - & 96 & 1.43 & $17 \cdot 44$ \\
\hline
\end{tabular}

* Onset of thermal denaturation. All values were measured from plots of initial heating run minus re-run (see Methods) and were the mean of two values.

$\dagger$ Peaks $m, n, p, q$ and $r$ are identified in Fig. 1. Numbers in parentheses: the identity of the first two peaks of $\boldsymbol{B}$. stearothermophilus was uncertain.

samples of $E$. coli peak $m$ was very broad, indicating the merging of two peaks, which were just resolved in some samples. Evidence of partially resolved, small peaks on the leading and falling edges of peak $m$ were seen in other organisms, e.g. $S$. faecalis var. liquefaciens. E. coli also exhibited an additional peak at about $119^{\circ} \mathrm{C}$, designated $r$ (Fig. $1 a$ ).

By contrast, the thermograms of vegetative cells differed markedly at temperatures below that of the highest peak $(m)$ (Fig. $1 a$ ). The true psychrophile $V$. marinus showed considerable structure in this region with the start of appreciable irreversible denaturation, determined from the difference plots (Fig. $1 \mathrm{~b}$ ), occurring at around $36^{\circ} \mathrm{C}$. Psychrotrophs began to denature at higher temperatures (around $42^{\circ} \mathrm{C}$ for $\mathrm{Br}$. thermosphacta, $47^{\circ} \mathrm{C}$ for $\mathrm{H}$. alvei and $49^{\circ} \mathrm{C}$ for $P$. fragi) and showed less structure in front of ' $m$ '. The mesophiles $E$. coli, $S$. faecium and $S$. faecalis var. liquefaciens started to denature at still higher temperatures, the onset (at $52{ }^{\circ} \mathrm{C}, 50^{\circ} \mathrm{C}$ and $50{ }^{\circ} \mathrm{C}$ respectively) leading via a point of inflexion to the main peak $m$. The thermophile $B$. stearothermophilus showed a sharp onset of denaturation at about $67^{\circ} \mathrm{C}$ from which point the thermogram climbed steeply to a double maximum at 79 and $82{ }^{\circ} \mathrm{C}$ and then fell to show small maxima at $94^{\circ} \mathrm{C}$ (possibly $p$ ) and $106^{\circ} \mathrm{C}$ (possibly $q$ ).

The temperature of onset of thermal denaturation was thus related to the thermal resistance of the different organisms, i.e. maximum growth temperatures (except for B. stearothermophilus) were always below the onset of thermal denaturation whilst the computed temperatures at which death rates were maximal were all above the onset of thermal denaturation. This was true for all the vegetative cells examined for which $D$ and $z$ values were tabulated by Tomlins \& Ordal (1976) (V. marinus, E. coli, P. fragi, S. faecalis and S. faecium) and Gardner (1981) (Br. thermosphacta). Maximum temperatures for growth were taken from Morita (1975), Gardner (1981) Tesone et al. (1981) and B. G. Shaw (personal communication).

The total enthalpy of denaturation of the bacteria was measured from the onset of denaturation $\left(T_{0}\right)$ to the end of peak $q$. After adjusting for dry mass the differences between bacteria were much larger than sample variations, values ranging from 9 to $20 \mathrm{~J}$ (g dry matter $)^{-1}$. Further work may establish if these differences are consistent for particular bacteria. Generally, and more markedly in some species, the denatured cells appeared to have a slightly higher specific heat capacity than viable cells, resulting in the level of the re-run thermogram being slightly higher at low temperatures than in the initial run (Fig. 1a).

All the vegetative cells showed a small endothermic peak $p_{r}$ [enthalpy of transition $1 \cdot 1$ to $2 \cdot 3 \mathrm{~J}$ (g dry matter) $)^{-1}$; Table 1 ] when samples were re-run after heating to $120^{\circ} \mathrm{C}$ and cooling to $5^{\circ} \mathrm{C}$. If the cells were initially heated to higher temperatures there was a tendency for $p_{r}$ to decline in size or disappear. $p_{r}$ showed a maximum at a similar temperature to $p$ (Table 1) but was noticeably sharper and generally of larger area. (Note the characteristic minima in the difference plots, Fig. $1 b$.) 

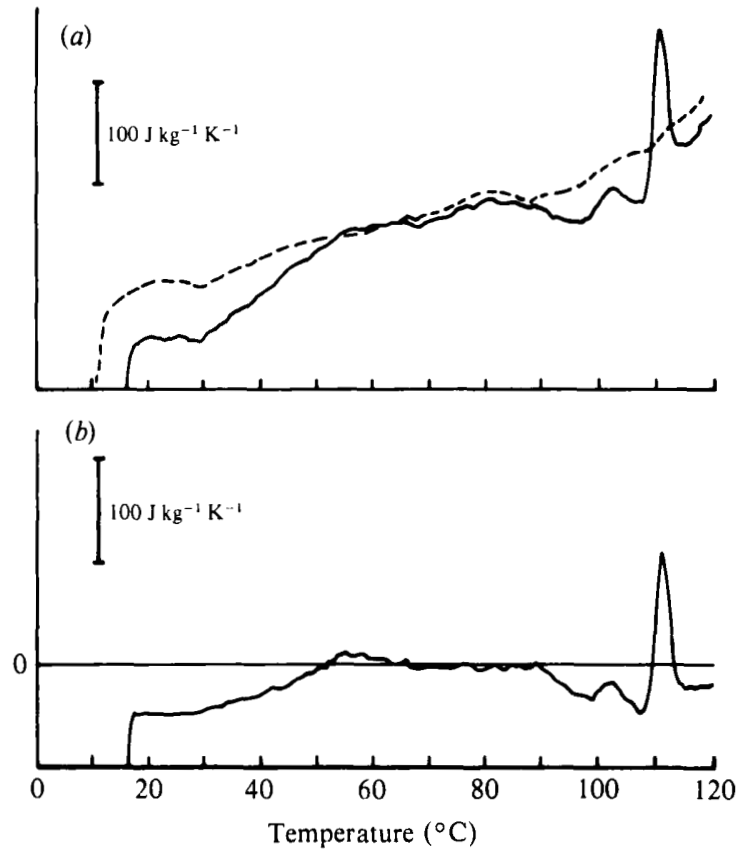

Fig. 2. Thermograms of spores of $B$. cereus. (a) - - Initial run; ----, re-run. (b) Difference plot: initial run minus re-run.

Thermogram of $B$. cereus spores

The thermogram of $B$. cereus spores (Fig. 2) differed markedly from those of the vegetative cells (Fig. 1). Its major feature was a multiple exothermic/endothermic process which started at about $90^{\circ} \mathrm{C}$ with the onset of an exotherm. The final endothermic peak occurred at about $110^{\circ} \mathrm{C}$ and some samples showed evidence of an endothermic peak at about $102{ }^{\circ} \mathrm{C}$, superimposed upon the exotherm.

\section{Identity of the thermogram peaks $p$ and $p_{r}$}

The temperatures at which peak $p$ occurred on thermograms were within the range of midpoint melting temperatures reported for purified bacterial DNA (Marmur \& Doty, 1962; De Ley, 1970). This and the apparent reversibility of the process (yielding $p_{r}$ when re-run) suggested it could represent melting of intracellular DNA, as previously suggested by Verrips \& Kwast (1977). Therefore one might expect a correlation between the temperatures at which $p_{r}$ is a maximum $\left(T_{\max }\right)$ and the percentage of $\mathrm{G}+\mathrm{C}$ base pairs in the DNA. This was indeed the case; $T_{\max }$ was highly correlated $\left[r=0.989\right.$, residual standard deviation (RSD) $\left.=0.42^{\circ} \mathrm{C}\right]$ with the mol fraction of $\mathrm{G}+\mathrm{C}$ base pairs in the DNA $\left(X_{\mathrm{GC}}\right)$ and the two properties were related by the following empirical regression equation:

$$
T_{\max }=30 \cdot 1 X_{\mathrm{GC}}+80 \cdot 2
$$

To define the relationship between $T_{\max }$ (determined by DSC) and $T_{m}$, the spectroscopically determined mid-point melting temperature of DNA (De Ley, 1970; Record et al., 1981), we examined the thermal denaturation of purified DNA from $E$. coli in solutions of different salt concentration. Fig. 3 shows experimentally-determined values of $T_{0}$ (the temperatures of onset of thermal denaturation) and $T_{\max }$ at different salt concentrations and compares these values with the corresponding values of $T_{m}$ calculated from the equation given by Record et al. (1981):

$$
T_{m}\left({ }^{\circ} \mathrm{C}\right)=176-\left(2.6-X_{\mathrm{GC}}\right)\left(36-3.06 \ln m_{3}\right)
$$

where $X_{\mathrm{GC}}$ was taken as 0.5 for $E$. coli DNA and $m_{3}$ is the molar concentration of salt. 


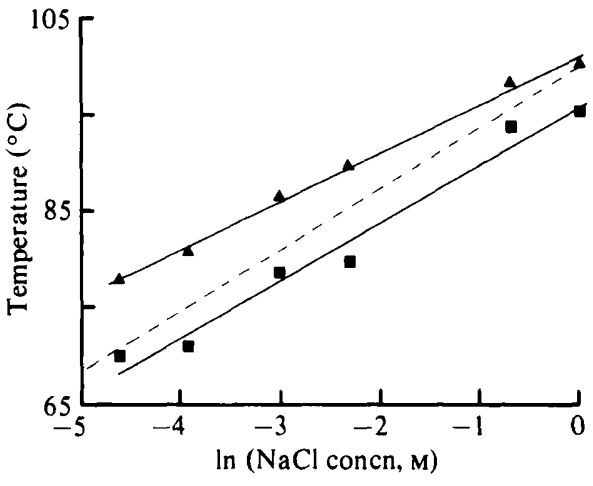

Fig. 3

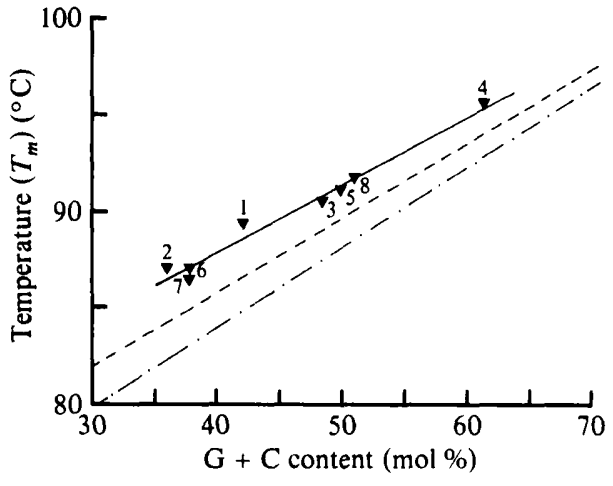

Fig. 4

Fig. 3. Relationship between melting of DNA from $E$. coli measured by DSC, calculated $T_{m}$ values and $\mathrm{NaCl}$ concentration. $\Delta, T_{\max }$, temperature at which DNA melting peak was maximal; ----, $T_{m}$, midpoint melting temperatures calculated according to Record et al. (1981); $\square, T_{0}$, temperature of onset of DNA melting taken from difference thermograms.

Fig. 4. Correlation between the mid-point melting temperature, $T_{m}$, and $\mathrm{G}+\mathrm{C}(\mathrm{mol} \%)$ content of DNA. $T_{m}$ was calculated (using equation 9) from measurements of $T_{\max }$ (peak $p_{r}$ in thermograms) using DSC of whole cells and plotted against the $\mathrm{G}+\mathrm{C}$ content reported in the literature for each species (see Methods). 1, V. marinus; 2, Br. thermosphacta; 3, H. alvei; 4, P. fragi; 5, E. coli; 6, S. faecalis var. liquefaciens; $7, S$. faecium and $8, B$. stearothermophilus. The least-squares line through the data $(-)$ is given by equation (10) and is compared to that obtained using either equations (5) from De Ley (1970) $(---)$ or (2) from Record et al. (1981) (-.-) with a $\mathrm{NaCl}$ concentration of $150 \mathrm{mM}$.

$T_{0}$ and $T_{m}$ increased linearly with the logarithm of the salt concentration and, as expected, $T_{m}$ lay between $T_{0}$ and $T_{\max }$ (Fig. 3). Values of $T_{m}$ for $E$. coli DNA predicted from equation (2) were highly correlated $\left(r=0.99, \mathrm{RSD}=0.43{ }^{\circ} \mathrm{C}\right)$ with DSC measurements of $T_{\max }$ in DNA solutions via the empirical regression equation:

$$
T_{m}=1.18 T_{\max }-20.9
$$

By combining equations (1) and (3) we may obtain an equation relating $T_{m}$ calculated from DSC data to the $G+C$ content of bacterial DNA:

$$
T_{m}=35.5 X_{\mathrm{GC}}+73.7
$$

This compares quite well (Fig. 4) with the equation of De Ley (1970) based on melting point measurements in standard saline/citrate buffer:

$$
T_{m}=39 X_{\mathrm{GC}}+70 \cdot 26
$$

Equations (4) and (5) agree within $3{ }^{\circ} \mathrm{C}$ over the measured range of $0.35<X_{\mathrm{GC}}<0.62$. Equally the values of $T_{m}$ predicted from our DSC results may be inserted into equation (2) to determine an apparent salt concentration $\left(m_{3}\right)$ inside the bacterial cell. The result that in $m_{3}=-1.36 \pm 0.09$ corresponds to a mean apparent concentration inside the cell of $257 \mathrm{~mm}$ and individual values ranged from 237 to $297 \mathrm{mM}$.

Details of the behaviour of purified $E$. coli DNA in the DSC are shown in Fig. 5. At high salt concentrations $(0.5 \mathrm{M}$ and above) the endothermic denaturation of DNA was fully reversible (Fig. 5a) and similar in appearance to peak $p_{r}$ observed in re-runs of the vegetative bacterial cells. However, at low salt concentrations $(0.1 \mathrm{M}$ and below; Fig. $5 b, c)$ endothermic processes were observed during the first heating cycle but subsequent cooling and re-heating sometimes produced an exothermic process with a maximum at about $90^{\circ} \mathrm{C}$ (reminiscent of a feature of the thermogram of the bacterial spore, Fig. 2). Finally, cooling and re-heating such samples revealed that the DNA had been irreversibly denatured (Fig. $5 c$ ). 


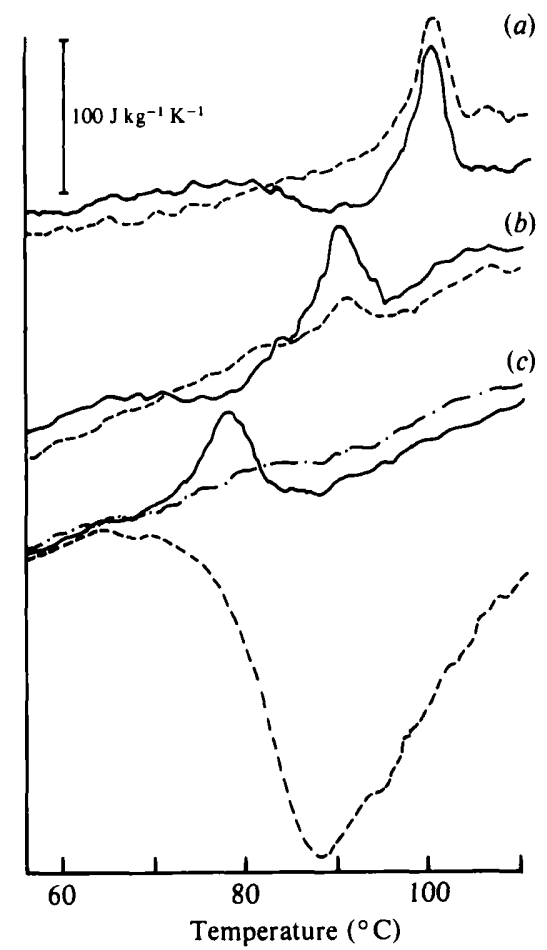

Fig. 5. Effect of salt concentration on thermograms of purified $E$. coli DNA. All solutions contained $10 \mathrm{mg} \mathrm{DNA} \mathrm{ml}^{-1}$ in $0.001 \mathrm{M}$-sodium citrate at $\mathrm{pH} 7.0$ and $\mathrm{NaCl}$ at $1.0 \mathrm{M}(a), 0.1 \mathrm{M}(b)$ or $0.01 \mathrm{M}(c)$. All thermograms $(-)$ were re-run after cooling $(----) ;(c)$ was also re-run a second time $(-\cdot-)$. No adjustment of settings or pans between original and re-runs was made. Positions of peak maxima on the initial heating run were reproducible to $\pm 0 \cdot 5^{\circ} \mathrm{C}$.

There was considerable scatter in our data for the enthalpy of DNA denaturation but little evidence that it was affected by salt concentration: the mean $\pm S D$, averaged over all salt concentrations, was $46 \pm 10 \mathrm{~J} \mathrm{~g}^{-1}$ and within the range of values (34 to $58 \mathrm{~J} \mathrm{~g}^{-1}$ ) reported for various DNAs (Sober, 1970). The measured value of the effective enthalpy of DNA melting may be used with the enthalpy of peak $\left.p_{r}[1.1 \text { to } 2.3 \mathrm{~J} \text { (g dry matter) })^{-1}\right]$ to predict the concentration of DNA present in vegetative cells, i.e. $2 \cdot 3$ to $5 \%$ of the dry matter.

\section{DISCUSSION}

When a bacterium is heated a reproducible sequence of endothermic or exothermic processes occurs within it causing small perturbations to the specific heat capacity of the cell. These perturbations can be observed by DSC, which reveals a characteristic pattern of peaks that record specific denaturation processes. Thus, when heat-denatured vegetative cells were heated at $10^{\circ} \mathrm{C} \mathrm{min}^{-1}$ a reversible endothermic peak, exhibiting a maximum in the range $90-100{ }^{\circ} \mathrm{C}$, was produced by the heat denaturation of the DNA of the cell. The half-width of the process was a few degrees (a fraction of a minute) and this process could be distinguished from other denaturation events occurring at different temperatures and times.

Thermograms of the vegetative cells had a characteristic appearance (Fig. 1) and were similar to the thermograms for Citrobacter freundii reported by Verrips \& Kwast (1977). Their data showed peaks at $70,83,92$ and $103^{\circ} \mathrm{C}$, which correspond with our $m, n, p$ and $q$ peaks, and points 
of inflexion on the leading edge of $m$, corresponding to similar features observed in some of our organisms. Ashe \& Steim (1971) reported that the main peak for Micrococcus lysodeikticus occurred at $76^{\circ} \mathrm{C}$ but their observations ended at $90^{\circ} \mathrm{C}$ and showed no clear peak beyond the main maximum. However, they made measurements with a different calorimeter, using larger samples, and their peak probably corresponds to our peak $m$, but it has been shifted to higher temperatures by a longer temperature lag in the sample.

There was a clear relationship between the onset of denaturation observed in the DSC and the thermal resistance of the organisms. Thus, in the cold-tolerant organisms $V$. marinus and $\mathrm{Br}$. thermosphacta, denaturation began at lower temperatures than in the mesophilic $E$. coli or the thermophilic B. stearothermophilus. Therefore, either some denaturation processes were present in the psychrophile and psychrotrophs which were absent (or inappreciable) in the more thermally stable organisms, or in the latter group the same denaturation processes occurred but at higher temperatures.

In all vegetative organisms the computed maximum death rates occurred at temperatures above the onset of thermal denaturation, i.e. cell death coincided with irreversible denaturation of cell components. Examination of thermograms (Fig. 1), however, showed that there was no common feature associated with maximum death rate in all organisms. In V. marinus death occurred at temperatures well in advance of the large endothermic peak $m$, whereas in $B r$. thermosphacta and $H$. alvei, death occurred at temperatures progressively closer to ' $m$ ' and in $E$. coli and the streptococci death coincided with peak $m$. It is possible that the critical lethal events differ between organisms or, alternatively, that similar processes are involved in each organism but occur at different temperatures, e.g. in $E$. coli these processes occur at $20^{\circ} \mathrm{C}$ higher than in $V$. marinus and are compounded with other substantial damage events represented by peak $m$.

Verrips \& Kwast (1977) suggested that in $C$. freundii the peak corresponding to our peak $m$ was caused by denaturation of the ribosome, but did not provide evidence. Our data support their hypothesis since there appears to be some correlation between $T_{\max }$ of peak $m$ for $V$. marinus $\left(73^{\circ} \mathrm{C}\right)$, E. coli $\left(69^{\circ} \mathrm{C}\right)$ and $B$. stearothermophilus $\left(79^{\circ} \mathrm{C}\right)$ and the corresponding $T_{m}$ values for ribosome melting given by Campbell \& Pace $(1968)$ of $67-74{ }^{\circ} \mathrm{C}, 72^{\circ} \mathrm{C}$ and $78-79{ }^{\circ} \mathrm{C}$ respectively. Clearly, further DSC studies on fractionated cell preparations are required to identify this peak conclusively. Extensive ribosome breakdown occurs when Salmonella typhimurium or Staphylococcus aureus are heated in phosphate buffer but not when they are heated in magnesium-containing buffers (Lee \& Goepfert, 1975; Hurst \& Hughes, 1978). Hurst (1984) argued that ribosome destruction was not a primary target of damage by heat but was an indirect consequence of magnesium loss from heated cells leading to dissociation of ribosomal subunits and activation of a latent ribonuclease. If peak $m$ does represent denaturation of the ribosome then, under our experimental conditions, ribosome destruction always occurred in heated cells but was not consistently related to maximum death rate.

The maximum growth temperatures reported for the different organisms were, as expected, below the onset of thermal denaturation, except for $B$. stearothermophilus. Precise determination of the temperature of onset of thermal denaturation $\left(T_{0}\right)$ is limited by background 'noise' in the thermograms. However, if the measured value of $T_{0}$ for this organism is correct, it implies that appreciable denaturation occurs at temperatures which permit growth. The resistance of thermophiles to heat has been attributed to $(a)$ the intrinsic stability of proteins and other macromolecules to heat, $(b)$ stabilization by protective factors within the cell and $(c)$ rapid turnover of heat denatured components. Substantial experimental evidence has been obtained only for mechanisms $(a)$ and $(b)$ (Zuber, 1979). However, whilst the evidence for $(c)$ remains controversial, rapid turnover of cell components as a contributory factor in thermotolerance cannot be ruled out, particularly where an organism is growing at temperatures close to its upper limit. Taken at their face value our results imply that turnover would be necessary in $B$. stearothermophilus growing above $67^{\circ} \mathrm{C}$ (the onset of thermal denaturation), but further evidence would be needed to confirm this.

Identification of peaks $p$ and $p_{r}$ as the melting endotherms of DNA within the bacterial cell was indicated by several lines of evidence. First, temperatures at which the process occurred 
were within the expected range for the melting of bacterial DNA and varied exactly as would be predicted from the known content of $\mathrm{G}+\mathrm{C}$ base pairs in the DNA; second, the process was reversible, consistent with the known renaturation properties of pure bacterial DNA; and third, the mass of DNA within $E$. coli, calculated from the enthalpy measurements, was in close agreement with reported values obtained by chemical analysis (Luria, 1960).

The apparent salt concentration inside $E$. coli, calculated by inserting values of $T_{m}$ and $X_{\mathrm{GC}}$ into the equation of Record et al. (1981), varied between 237 and $297 \mathrm{mM}$, which is close to the reported intracellular cation concentration of 260-300 mM (Schulze et al., 1963). The melting temperature of $E$. coli DNA within the cell measured from peak $p_{r}$ thus seemed to depend mainly on the internal ionic strength. However, bacterial DNA exists intracellularly as a folded structure stabilized by interaction with RNA, protein and polyamines (Stonington \& Pettijohn, 1971; Worcel \& Burgi, 1972). Interactions with other molecules in vitro have been shown to increase the melting temperature of DNA. For example, the $T_{m}$ in $0 \cdot 1 \mathrm{M}-\mathrm{NaCl}$ for denaturation of double helical DNA from E. coli was increased from 85 to $90^{\circ} \mathrm{C}$ by addition of $5 \mathrm{~mm}$ spermidine (Flink \& Pettijohn, 1975) and polyarginine induced a biphasic melting profile in DNA from E. coli and other micro-organisms (Epstein et al., 1974). Interactions of this sort in vivo should result in a broadening of the DNA melting profile and/or the appearance of additional peaks at high temperature due to the melting of stabilized DNA complexes. It is therefore possible that thermogram features additional to $p$ and $p_{r}$ represent melting of DNA.

The existence of stabilizing interactions might also explain differences between $p$ and $p_{r}$. Peak $p_{r}$ was larger and sharper than $p$, implying that more DNA melted at this temperature during the second heating cycle. This could occur if DNA melting was multiphasic during the first heating cycle but the stabilizing interactions were themselves disrupted by heat, thus restoring the melting point of a fraction of the DNA to the lower temperature.

A heat-induced change in the structure of the folded DNA structure (nucleoid) of $E$. coli was described by Pellon et al. $(1980,1982)$. During exposure to mild heat $\left(50^{\circ} \mathrm{C}\right)$ the sedimentation coefficient of the nucleoid changed and new proteins were synthesized which subsequently became associated with the nucleoid during repair of thermal injury. Cells heated at $10^{\circ} \mathrm{C} \mathrm{min}-1$ in the DSC remain viable for a few minutes only and it therefore seems unlikely that the heatinduced protein described by Pellon et al. $(1980,1982)$ would have been synthesized in sufficient amounts to affect the melting profile of DNA seen in the DSC.

The denaturation characteristics of purified $E$. coli DNA in the DSC were in agreement with results obtained by other methods (Marmur \& Doty, 1962; Dove \& Davidson, 1962), i.e. the melting temperature increased linearly with the logarithm of the ionic strength and renaturation occurred optimally in solutions of high ionic strength.

The large exothermic process which occurred on re-heating DNA at low ionic strength was unexpected and cannot be explained at present. The size of the enthalpy change could suggest that covalent bonding reactions were involved and, though several possible reactions have been described, including de-purination, de-pyrimidation and de-amination, these do not occur at significant rates at temperatures where the exotherm was observed (Greer \& Zamenhof, 1962; Shapiro \& Klein, 1966; Shapiro \& Danzig, 1972; Lindahl \& Nyberg, 1972). An alternative possibility is that some change in the state of the DNA occurred during re-heating, e.g. formation of a thermosetting gel.

Equation (4) relating the melting point of DNA, determined by in situ DSC measurements, to the $G+C$ content of bacterial DNA, was very similar to the standard equation (5) of De Ley (1970). DSC thus offers a simple way to determine $G+C$ values without first having to purify DNA : samples of whole cells grown on agar plates or centrifuged from broth cultures could be placed directly in the DSC and the G $+C$ content calculated from the temperature of peak $p_{r}$. Clearly, a wider range of bacteria should now be examined to obtain a more accurate relationship between $T_{m}$ and $X_{\mathrm{GC}}$.

By the use of DSC, we have shown for the first time that the heat resistance of different microorganisms is related to the thermostability of their cell components in situ. By identifying the particular cell components associated with thermogram peaks we should be able to define the sequence of denaturation events that occurs during thermal inactivation of micro-organisms. 


\section{A P PENDIX}

\section{Thermal death rates of bacteria in the DSC}

Two parameters are often used to describe the rate at which bacterial cells are killed. The $D$ value, at a particular temperature, is the time taken for the number of surviving cells to be reduced by a factor of 10 . The $z$ value is the increase in temperature required to reduce the $D$ value 10 -fold.

If it is assumed that thermal death in micro-organisms is a first order process, then:

$$
\frac{\mathrm{d} N}{\mathrm{~d} t}=-k N
$$

and from the definition of $D$ given above:

$$
k=\frac{2 \cdot 303}{D}
$$

[see equations (1) to (4) of Stumbo (1965)]. Similarly, by assuming the change of $D$ with respect to temperature to first order;

$$
\frac{\mathrm{d} D}{\mathrm{~d} T}=\frac{-D}{A}
$$

where

$$
A=\frac{z}{2 \cdot 303}
$$

Integration of equation (7) results in an equation relating $D$ at any arbitrary temperature $T$ to $A$ and the value $\left(D_{e}\right)$ at a particular temperature $T_{e}$ :

$$
D=D_{e} \exp \left\{\frac{T_{e}-T}{A}\right\}
$$

Inserting equation (8) in (6) gives:

$$
\frac{\mathrm{d} N}{\mathrm{~d} t}=\frac{-2 \cdot 303 N}{D_{e}} \exp \left\{\frac{T-T_{e}}{A}\right\}
$$

If, at instant $t=0$, the temperature of the sample is increased from $T_{0}$ at a constant rate $r$, the temperature at any instant is given by:

$$
T=T_{0}+r t
$$

and

$$
\mathrm{d} T=r \mathrm{~d} t
$$

The number of survivors at any temperature is given by inserting equation (10) in (9) and integrating:

$$
\int_{N_{0}}^{N} \frac{\mathrm{d} N}{N}=\frac{-2 \cdot 303}{D_{e} r} \int_{T_{0}}^{T} \exp \left\{\frac{T-T_{e}}{A}\right\} \mathrm{d} T
$$

i.e.

$$
\frac{N}{N_{0}}=\exp \left\{\frac{-z}{D_{e} r}\left[\exp \left(\frac{T-T_{e}}{A}\right)-\exp \left(\frac{T_{0}-T_{e}}{A}\right)\right]\right\}
$$


The rate at which the population is killed per unit time is obtained by inserting equation (11) in equation (9):

$$
\frac{1}{N_{0}} \frac{\mathrm{d} N}{\mathrm{~d} t}=\frac{-2 \cdot 303}{D_{e}} \exp \left\{\frac{T-T_{e}}{A}\right\} \exp \left\{\frac{-z}{D_{e} r}\left[\exp \left(\frac{T-T_{e}}{A}\right)-\exp \left(\frac{T_{0}-T_{e}}{A}\right)\right]\right\}
$$

and the rate at which the population is killed per unit increase in temperature can be calculated from equation (12) using the relation:

$$
\frac{1}{N_{0}} \frac{\mathrm{d} N}{\mathrm{~d} T}=\frac{1}{r N_{0}} \frac{\mathrm{d} N}{\mathrm{~d} t}
$$

The temperature $T_{D_{\max }}$ at which the death rate is a maximum may be calculated by differentiating the logarithm of equation (12) and setting it equal to zero, from which:

$$
T_{D_{\max }}=T_{e}+\frac{z}{2 \cdot 303} \ln \left(\frac{D_{e} r}{z}\right)
$$

The width of the peak may be described by its width at half the peak height; this is called the 'half-width', $\Delta T$. The temperatures $T_{D_{\max }}+\delta$ either side of the maximum at this level may be obtained by setting the ratio of the peak heights at $T_{D_{\max }}$ and at $T_{D_{\max }}+\delta$ equal to 2 :

$$
2=\exp \left(\frac{-\delta}{A}\right) \exp \left\{\frac{-z}{D_{\iota} r} \exp \left(\frac{-T_{e}}{A}\right)\left[\exp \left(\frac{T_{D_{\max }}}{A}\right)-\exp \left(\frac{T_{D_{\max }}+\delta}{A}\right)\right]\right\}
$$

Inserting the identity

$$
\frac{z}{D_{\iota} r} \exp \left(\frac{T_{D_{\max }}-T_{t}}{A}\right)=1
$$

and taking logarithms of both sides yields:

$$
\exp \left(\frac{\delta}{A}\right)=\left(\frac{\delta}{A}\right)+1+\ln 2
$$

This has two roots, corresponding to the two temperatures, either side of the peak:

$$
\frac{\delta}{A}=-1.461 \quad \text { and } \quad \frac{\delta}{A}=0.985
$$

and the half-width

$$
\Delta T=\frac{2 \cdot 446}{2 \cdot 303} z=1.062 z
$$

Equations (12) \& (13) were used to calculate $1 / N_{0} \mathrm{~d} N / \mathrm{d} T$ for hypothetical bacteria showing a range of $D$ and $z$ values (Fig. Al). Calculations were insensitive to precise values of $T_{0}$ provided this was low and for the purpose of this work it was set equal to $10^{\circ} \mathrm{C}$. The death rate for each organism was low or zero at low temperatures but increased eventually with temperature, slowly at first and then more rapidly to a maximum rate at a temperature denoted by $T_{D_{\max }}$ (Fig. Al). Further increase in temperature caused a rapid decline in the death rate. The result was a somewhat asymmetric, single-peaked curve. Increasing $z$, while keeping other parameters constant, increased the half-width proportionately (Fig. Al $a$ ) as predicted by equation (15). $T_{D_{\max }}$ increased in proportion to the logarithm of $D$ (Fig. Al $b$ ) and the logarithm of the heating rate (Fig. Alc), as predicted by equation (14), and as expected (equation 15) variations in $D$ and $r$ did not affect the half-width $\Delta T$.

The temperature at which death rate was a maximum, $T_{D_{\max }}$, and the half-width, $\Delta T$, were calculated using equations (14) and (15) for five vegetative bacterial cells: $E$. coli, $S$. faecalis var. liquefaciens, $S$. faecium, $P$. fragi and $V$. marinus, and spores of $B$. cereus (Table Al). $D$ and $z$ values for these organisms were taken from published work tabulated in the review of Tomlins \& Ordal (1976). Whereas different references gave markedly different values of $D$ and $z$ for the same organism and there was considerable variation in the half-width (see data for $E$. coli and $S$. 

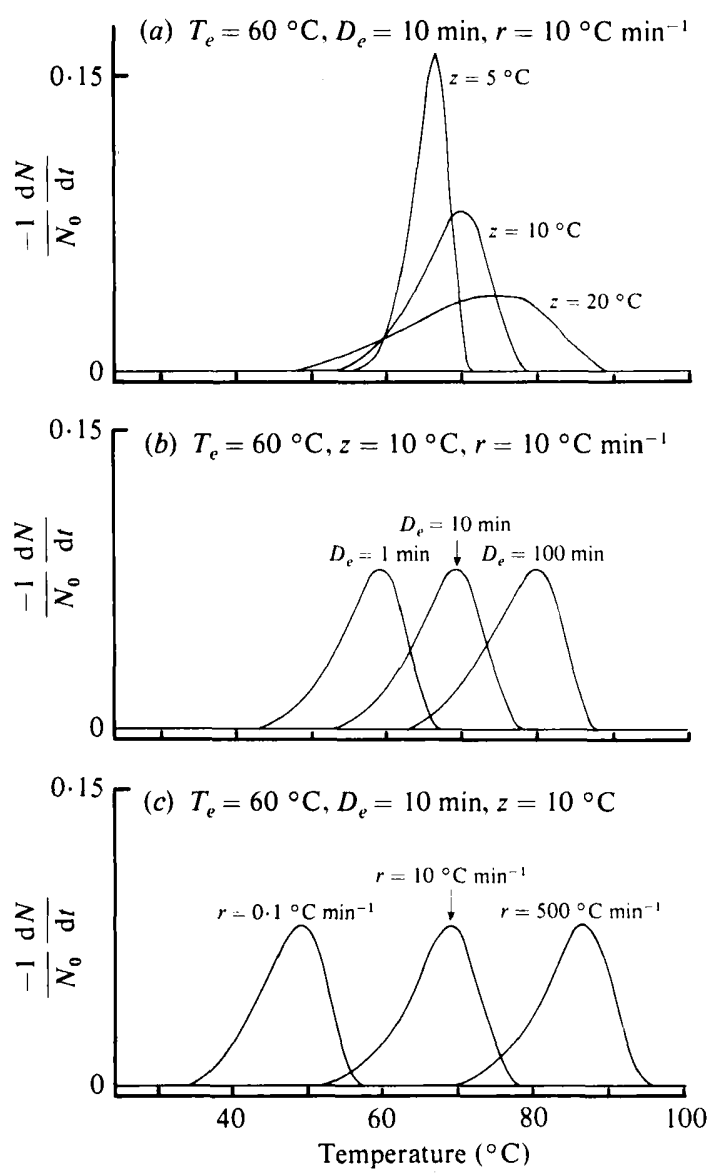

Fig. Al. Models of death rates for bacteria heated at a constant rate, $r$. Calculations were made on the basis of equations (12) and (13) for various values of $z, D_{e}\left(D\right.$ value at temperature $\left.T_{e}\right)$ and $r$. $(a)$ Effect of varying $z$ at constant $D$ and $r ;(b)$ effect of varying $D$ at constant $r$ and $z ;(c)$ effect of varying $r$ at constant $D$ and $z$.

faecalis var. liquefaciens, Table A1) the temperatures, $T_{D_{\max }}$, at which the death rate was highest were similar.

Equations (6), (7) and (10) upon which the above calculations are based are approximations to the real behaviour of organisms in a DSC and are subject to certain qualifications. Inactivation of bacteria in the DSC may not conform strictly to the first order rate kinetics assumed in the calculations; if, for example, a shoulder were present, values of $T_{D_{\max }}$ would be too low. The equations also assume that $z$ does not change with temperature; this may not necessarily be so and calculations are only strictly valid for temperatures within the range where $D$ and $z$ were determined. No allowance is made for possible growth of organisms at low temperatures which might affect inactivation rates at low heating rates. Conversely, at high heating rates the analysis is likely to be unrealistic due to the establishment of appreciable thermal gradients within the sample.

Values of $T_{D_{\max }}$ calculated for organisms used in the present work were, as expected, consistent with their known thermal resistances: the particular calculated values of $T_{D_{\max }}$ may, however, be subject to errors arising from differences between our strains and those whose $D$ and $z$ values are reported in the literature, and differences between heating conditions in the DSC and those used for determination of reported $D$ and $z$.

We thank Dr.R. A. Maciewicz, Dr T. A. Roberts and Dr B. G. Shaw for discussion, Mrs D. A. Seymour for help in preparing bacterial samples and Mr G. A. J. Fursey for help in computer analysis of the calorimetric data. S. E.P. took part in this study while in receipt of a MAFF research grant. 
Table A1. Calculated death rate characteristics of bacteria heated at a constantly rising temperature of $10^{\circ} \mathrm{C} \mathrm{min}^{-1}$

\begin{tabular}{|c|c|c|c|c|c|c|}
\hline Organism & Heating medium & $\begin{array}{c}T_{e}^{*} \\
\left({ }^{\circ} \mathrm{C}\right)\end{array}$ & $\underset{(\min )}{D \dagger}$ & $\begin{array}{c}z \dagger \\
\left({ }^{\circ} \mathrm{C}\right)\end{array}$ & $\underset{\left({ }^{\circ} \mathrm{C}\right)}{T_{D_{\text {max }}} \ddagger}$ & $\begin{array}{l}\Delta T \S \\
\left({ }^{\circ} \mathrm{C}\right)\end{array}$ \\
\hline V. marinus & Seawater broth & 31 & 11 & $9 \cdot 5$ & 41 & 10 . \\
\hline Br. thermosphacta & $\begin{array}{l}\text { Skim milk, phosphate } \\
\text { buffer }\end{array}$ & 55 & 1 & 8 & 56 & \\
\hline P. fragi & Cheese & $54 \cdot 5$ & 2 & 11 & 57 & 11 . \\
\hline \multirow[t]{3}{*}{ E. coli } & Nutrient broth & 56 & $4 \cdot 5$ & 4.9 & 61 & \\
\hline & Milk solution $(10 \%)$ & 58 & $1 \cdot 4$ & $4 \cdot 6$ & 60 & \\
\hline & Milk & $82 \cdot 2$ & $5.7 \times 10^{-4}$ & 6.5 & 62 & 0 \\
\hline $\begin{array}{l}\text { S. faecalis var. } \\
\text { liquefaciens }\end{array}$ & Broth & 60 & 5 & 19 & 68 & 20 \\
\hline \multicolumn{7}{|l|}{ S. faecium } \\
\hline Group I & Broth & 60 & 15 & 3 & 65 & \\
\hline Group II & & 60 & 11 & $3 \cdot 5$ & 65 & \\
\hline Group IV & & 60 & 8 & $2 \cdot 5$ & 64 & 2 \\
\hline B. cereus spores & Low acid food, $\mathrm{pH} 4.6$ & 100 & 5 & 10 & 107 & 10 \\
\hline
\end{tabular}

* Temperature at which $D$ was determined.

$\dagger$ Values for $D$ and $z$ were from Tomlins \& Ordal (1976) except for Br. thermosphacta and B. cereus spores which were from Gardner (1981) and Olson \& Nottingham (1980), respectively.

$\ddagger$ Temperature at which death rate was maximal, calculated as described in the Appendix (equation 14).

$\S$ Half-width of the death rate peak at half its maximum height, calculated as described in the Appendix (equation 15).

\section{REFERENCES}

Ashe, G. B. \& Stelm, J. M. (1971). Membrane transitions in Gram-positive bacteria. Biochimica et biophysica acta 233, 810-814.

BaumanN, P., Furniss, A. L. \& Lee, J. V. (1984). Genus Vibrio. In Bergey's Manual of Systematic Bacteriology, vol. 1, pp. 518-538. Edited by N. R. Kreig \& J. G. Holt. Baltimore: Williams \& Wilkins.

BEUCHAT, L. R. (1978). Injury and repair of Gramnegative bacteria with special consideration of the involvement of the cytoplasmic membrane. $A d$ vances in Applied Microbiology 23, 219-243.

Campbell, L. L. \& PACE, B. (1968). Paper III: physiology of growth at high temperatures. Journal of Applied Bacteriology 31, 24-35.

Collins-Thompson, D. L., Sørhang, T., Witter, L. D. \& ORDAL, Z. J. (1972). Taxonomic consideration of Microbacterium lactium, Microbacterium flavum and Microbacterium thermosphactum. International Journal of Systematic Bacteriology 22, 65-72.

DE LEY, J. (1970). Re-examination of the association between melting point, buoyant density and chemical base composition of deoxyribonucleic acid. Journal of Bacteriology 101, 738-754.

Dove, W. F. \& DAvidson, N. (1962). Cation effects on the denaturation of DNA. Journal of Molecular Biology 5, 467-478.

Epstein, P., YU, S. S. \& LI, H. J. (1974). Helix-coil transition and conformational studies of nucleoprotein: poly(L-arginine)- and poly(L-arginine ${ }^{87}$, Lornithine ${ }^{13}$-DNA complexes. I. Thermal denaturation. Biochemistry 13, 3706-3712.

Farrow, J. A. E., Jones, D., Phillips, B. A. \& Collins, M. D. (1983). Taxonomic studies on some group D streptococci. Journal of General Microbiology 129, 1423-1432.

Flink, I. \& Pettijohn, D. E. (1975). Polyamines stabilise DNA folds. Nature, London 253, 62-63.

GARDNER, G. A. (1981). Brochothrix thermosphacta
(Microbacterium thermosphactum) in the spoilage of meats: a review. In Psychrotrophic Micro-organisms in Spoilage and Pathogenicity, pp. 139-173. Edited by T. A. Roberts, G. Hobbs, J. H. B. Christian \& N. Skovgaard. London \& New York: Academic Press GibSON, T. \& GoRdON, R. E. (1974). Genus Bacillus. In Bergey's Manual of Determinative Bacteriology, 8th edn, pp. 529-550. Edited by R. E. Buchanan \& N. E. Gibbons. Baltimore: Williams \& Wilkins.

GoNDA, K. \& KOGA, S. (1973). Low-temperature thermograms of Saccharomyces cerevisiae. Journal of General and Applied Microbiology 19, 393-396.

Greer, S. \& ZamenhoF, S. (1962). Studies on depurination of DNA by heat. Journal of Molecular Biology 4, 123-141.

HURST, A. (1984). Revival of vegetative bacteria after sublethal heating. In The Revival of Injured Microbes, pp. 77-103. Edited by M. H. E. Andrew \& A. D. Russell. London: Academic Press.

HuRST, A. \& Hughes, A. (1978). Stability of ribosomes of Staphylococcus aureus S6 sublethally heated in different buffers. Journal of Bacteriology 133, 564568.

Lawton, W. D., Morris, B. C. \& Burrows, T. W. (1968). Gene transfer in strains of Pasteurella pseudotuberculosis. Journal of General Microbiology 52, 25-34

LEE, A. C. \& Goepfert, J. M. (1975). Influence of selected solutes on thermally induced death and injury in Salmonella typhimurium. Journal of Milk and Food Technology 38, 195-200.

LINDAHL, T. \& NYBERG, B. (1972). Rate of depurination of native deoxyribonucleic acid. Biochemistry 11, 3610-3618.

LURIA, S. E. (1960). The bacterial protoplasm: composition and organisation. In The Bacteria 1, pp. 1-34. Edited by I. C. Gunsalus \& R. Y. Stanier. New York \& London: Academic Press. 
MCElhaney, R. N. (1982). The use of differential scanning calorimetry and differential thermal analysis in studies of model and biological membranes. Chemistry and Physics of Lipids 30, 229-259.

Maeda, Y., Noguchi, S. \& Koga, S. (1974). Differential scanning calorimetric study of spontaneous germination of Bacillus megaterium spores by water vapour. Journal of General and Applied Microbiology 20, $11-19$.

Maeda, Y., Teramoto, Y. \& Koga, S. (1975). Calorimetric study on heat activation of Bacillus cereus spores. Journal of General and Applied Microbiology 21, 119--122.

Marmur, J. \& Doty, P. (1962). Determination of the base composition of deoxyribonucleic acid from its thermal denaturation temperature. Journal of Molecular Biology 5, 109-118.

Morita, R. Y. (1975). Psychrophilic bacteria. Bacteriological Reriews 39.144-167.

Olson, J. C. \& Nottingham, P. M. (1980). Temperature. In Microbial Ecology of Foods, rol. 1. (Factors Affecting Life and Death of Microorganisms) pp. 1-37. Edited by The International Commission on Microbiological Specification for Foods. London \& New York: Academic Press.

Pellon, J. R. \& Sinskey, A. J. (1984). Heat induced damage to the bacterial chromosome and its repair. In The Revival of Injured Microbes. Society for Applied Bacteriology Symposium, Series No. 12, pp. 105-125. Edited by M. H. E. Andrew \& A. D. Russell London: Academic Press.

Pellon, J. R., Ulmer, K. M. \& Gomez, R. F. (1980). Heat damage to the folded chromosome of $E$. coli K-12. Applied and Environmental Microbiology 40. $358-364$.

Pellon, J. R., Gomez, R. F. \& Sinskey, A. J. (1982). Association of the $E$. coli nucleoid with protein synthesized during thermal treatments. In Heat Shock: from Bacteria to Man, pp. 121-125. Edited by M. J. Schlesinger, M. Ashburner \& A. Tissieres. Cold Spring Harbor, New York: Cold Spring Harbor Laboratory.

Pierson, M. D., Gomez, R. F. \& Martin, S. E. (1978). The involvement of nucleic acids in bacterial injury. Adrances in Applied Microbiologl 23, 263-285.

Record, M. T., Mazur, S. J., Jr, Melancon, P., Roe, J.-H., Shaner, S. L. \& Unger, L. (1981). Double helical DNA: conformations, physical properties and interactions with ligands. Annual Reriews of Biochemistry 50, 997-1024.

SAKAZAKI, R. (1984). Genus Hafinia. In Bergey's Manual of Systematic Bacteriology, vol. 1, pp. 484 486. Edited by N. R. Kreig \& J. G. Holt. Baltimore: Williams \& Wilkins.
Schulze, S. G., Epstein, W. \& Solomon, A. K. (1963). Cation transport in Escherichia coli. IV. Kinetics of net K uptake. Journal of General Physiology 47, 329 346.

SHAPIRO, R. \& DANZIG, M. (1972). Acidic hydrolysis of deoxycytidine and deoxyuridine derivatives. The general mechanism of deoxyribonucleoside hydrolysis. Biochemistry 11, 23-29.

ShapiRo, R. \& KLEIN, R. S. (1966). The deamination of cytidine and cytosine by acidic buffer solutions. Mutagenic implications. Biochemistry 5, 2358-2362.

SOBER, H. A. (editor) (1970). Handbook of Biochemistry: Selected Data for Molecular Biology, 2nd edn. Boca Raton: CRC Press.

Stonington, O. G. \& Petrijohn, D. E. (1971). The folded chromosome of E. coli isolated in a proteinDNA-RNA complex. Proceedings of the National Academy of Sciences of the United States of America 68, 6.9.

Stumbo, C. R. (1965). Thermobacteriology in Food Processing, pp. 58-59. New York \& London: Academic Press

Tesone, S., Hughes, A. \& Hurst, A. (1981). Salt extends the upper temperature limit for growth of food poisoning bacteria. Canadian Journal of Microbiology 27, 970-972.

TOMLINS, R. I. \& ORdaL, Z. J. (1976). Thermal injury and inactivation in vegetative bacteria. In Inhibition and Inactivation of Vegetatice Microbes. Society for Applied Bacteriology, Symposium Series No. 5, pp. 153-190. Edited by F. A. Skinner \& W. B. Hugo. London: Academic Press.

Van Cauwelaert, F. H. \& Verbeke, M. N. (1979). Differential scanning calorimetric observations concerning the activation mechanism of spores of Phycomyces blakesleeanus. Biochemical and Biophysical Research Communications 89, 414-419.

Verbeke, M. N.. VAN CaUwelaert, F. H. \& Jadot, R. (1981). Calorimetric aspects of heat activation of spores of Phycomyces blakesleeanus. Biochemical and Biophysical Research Communications 98, 915921.

VERRIPS, C. T.\& KWAST, R. H. (1977). Heat resistance of Citrobacter freundii in media with various water activities. European Journal of Applied Microbiolog.' 4, 225-231.

Worcel, A. \& Burgi, E. (1972). On the structure of the folded chromosome of E. coli. Journal of Molecular Biology 71, 127-147.

ZUBER, H. (1979). Structure and function of enzymes from thermophilic microorganisms. In Strategies of Microbial Life in Extreme Encironments, pp. 393-415. Edited by $\mathbf{M}$. Shilo. Berlin: Dahlem Konferenzen, Verlag Chemie. 